\title{
NEUROPROTECTIVE ACTIVITY OF FRACTIONAL FLOWER EXTRACTS OF MIRABILIS JALAPA AGAINST ALUMINIUM HYDROCHLORIDE INDUCED NEUROTOXICITY IN MALE WISTER RATS
}

\author{
SITTY MANOHAR BABU*, SURYAKANTA SWAIN, KARANAM RENUKA \\ Southern Institute of Medical Sciences, College of Pharmacy, SIMS Group of Institutions, Mangaladas Nagar, Vijayawada Road, Guntur \\ 522001, Andhra Pradesh, India \\ Email: sittymanoharbabu@gmail.com
}

Received: 18 Jun 2016 Revised and Accepted: 31 Mar 2017

\begin{abstract}
Objective: The major objective of this present study was to evaluate the neuroprotective effect of fractional flower extracts (acetone, petroleum ether, methanol and aqueous) of Mirabilis jalapa (MJ) against aluminium hydrochloride-induced neurotoxicity in male wister rats.

Methods: From the different fractional flower extracts of Mirabilis jalapa (M)), two doses ( 250 and $500 \mathrm{mg} / \mathrm{kg}$ body weight) of each extract was initially selected and administered per orally $30 \mathrm{~min}$ prior to aluminium hydrochloride administration to the different animal groups once a day for a period of $45 \mathrm{~d}$. Rat serum was collected from different animal groups on $11^{\text {st }}, 15^{\text {th }}, 30^{\text {th }}$ and $45^{\text {th }}$ days for estimation of marker enzymes, where a reduction in marker was observed. Animal was sacrificed by decapitation and the whole brain of rats was analyzed to estimate the levels of nitrite, thiobarbituric acid reactive substances (TBARS), superoxide dismutase (DOS), catalase, reduced glutathione and acetylcholinesterase (AchE)

Results: On the $9^{\text {th }}$ day the Wister rats were sacrificed and cerebral cortex was removed. One-half of the cerebral cortex samples from different groups of Aluminium hydrochloride treated rats were stored in FAM mixture (40\% formaldehyde, acetic acid and methanol in the ratio of 1:1:8) for histological analysis. From the study confirmed that dose of 250 and $500 \mathrm{mg} / \mathrm{kg}$ bwt of methanolic extract of $M J$ significantly (p<0.001) increases the reduced glutathione, superoxide dismutase and catalase level, whereas petroleum ether, acetone and aqueous fractional flower extracts of $M J$ significantly $(\mathrm{p}<0.01)$ decreases nitrite, TBARS and AchE levels of aluminium hydrochloride treated groups.
\end{abstract}

Conclusion: This result is indicating evidence for Mirabilis jalapa had a significant neuroprotective effect on aluminium hydrochloride-induced neurotoxicity and also supports by histopathological studies.

Keywords: Mirabilis jalapa, Memantine, Oxidative stress, Thiobarbituric acid reactive substances, Neuroprotective activity

(C) 2017 The Authors. Published by Innovare Academic Sciences Pvt Ltd. This is an open access article under the CC BY license (http://creativecommons.org/licenses/by/4.0/) DOI: http://dx.doi.org/10.22159/ijpps.2017v9i5.17584

\section{INTRODUCTION}

Mirabilis jalap (Four $0^{\prime}$ Clock flower or marvel of Peru) is a perennial herb or under a shrub belonging to the family Nyctaginaceae and it is the most commonly growing ornamental species of mirabilis found throughout india. The plant is decorative and a favourite garden plant with red, white, yellow, pink, purple and orange flowers. Mirabilis jalapa and its different extract are used in traditional medicine in various countries for the treatment of diarrhea, dysentery, conjunctivitis, edema, inflammation, swellings, abdominal colics and muscular pain, antibacterial, antiviral and antifungal etc [1]. Aqueous extract of Mirabilis jalapa increases the level of nitrites AchE, TBARS, reduction of glutathione (GSH), catalase and SOD (Superoxide dismutase) in rat cerebral cortex [2]. Aluminium hydrochloride metal is abundantly present in the earth crust and the environment it gets access to the human body via the gastrointestinal and the respiratory tracts. The daily intake of aluminium hydrochloride is estimated to be approximately 10-20 mg of cooking utensils, food additives, and medicine such as antacid or deodorants. Accumulation of aluminium hydrochloride in brain induces pathophysiology of neurodegenerative including Alzheimer's, dementia, amylotrophic, lateral sclerosis, GuamParkinson's dementia etc [3]. Since a variety of biomolecules are bound to aluminium hydrochloride so it can displace the other biological cations (calcium and magnesium) from their binding sites in every metabolic pathway and shows the adverse effect of aluminium hydrochloride of the potential target site. Therefore, aluminium hydrochloride neurotoxicity is not caused by a single alteration, but it is probably a result of adverse effects at multiple cellular levels. Aluminium hydrochloride interacts with the cholinergic projection function and intensifying the inflammation in the pathological process of Alzheimer's, diseases (AD) [4]. Aluminium hydrochloride salts in biological tissue do not have any direct pro-oxidant properties; in fact, it potentiates the ability of iron salts to promote reactive oxygen species formation (ROS) [5]. In addition, aluminium hydrochloride has been reported to enhance peroxidative damage to lipid, protein and decrease antioxidant enzymes status. Aluminium hydrochloride has a potential to get accumulated in specific brain regions, which were earlier correlated with the degenerative changes [6].

Enhancement of cholinergic neurotransmission represents an important target for treating adult-onset cognitive disorders memantine is uncompetitive NMDA receptor antagonist. Several studies have shown that the drug produces a dose-related effect on cognitive function that was correlated with the degree of acetylcholinesterase inhibition in the cerebrospinal fluid [7]. From reported literature P. Selvakumar et al., performed a study on phytochemical screening and antioxidant activity of red flowered mirabilis jalapa leaf in different solvents. Keeping these things in mind the authors have examined the protective effect of Mirabilis jalapa flower extract on the impairment of cholinergic and antioxidant activity induced by aluminium hydrochloride in the cerebral cortex of male Wister rats. Apart from these histopathological studies is also undertaken to determine the morphological alteration in the cerebral cortex.

\section{MATERIALS AND METHODS}

Identification of plant collection

The flowers of Mirabilis jalapa was collected, identified and authenticated by Mr. M. R. Paul Satyakeerthi, head of the development, department of Botany of Andhra Christian College, Guntur, Andhra Pradesh, India. A voucher specimen (BSI/SC/ 5/23/09-10/Tech/1616) has been deposited at the Department of Botany of Andra Christian College, Guntur for species identification of Mirabilis jalapa. 


\section{Animals}

Healthy male Wister rats strain weighing $250 \pm 20 \mathrm{~g}$ was obtained from the Mahaveera enterprises, Hyderabad, India. Animals were allowed to acclimatize for at least $1 \mathrm{w}$ prior to start experiments. The animals were housed in polypropylene cages under pathogen free at uniform conditions of light $(12 \mathrm{~h})$ and dark (12h) cycle at a temperature of $24 \pm 2{ }^{\circ} \mathrm{C}$. They were fed with standard pellet diet (Hindustan Lever Limited, India). Their health status was checked frequently. All the experiment was performed in the morning and in accordance with the guidelines provided by the Institutional Animal Ethics Committee with approval number (Ethical Reg. Approval No. IAEC/SIMS 2014/001).

\section{Chemicals and reagents}

Mirabilis jalapa, memantine, aluminium hydrochloride chloride and sodium carboxymethyl cellulose (SD Fine Chemicals, Mumbai, India).

\section{Preparation of different fractional extract of Mirabilis jalapa} flowers

Flowers extract of Mirabilis jalapa was performed according to the method of the National Institute of Health and Family Welfare NIHFW, New Delhi. Flowers were collected from the plant, wash with water and dried under the shadow and made into coarse powder. The powder material was initially defatted with petroleum ether followed after $72 \mathrm{~h}$ extractions, by the addition of acetone, petroleum ether, methanol and water respectively. The solvent eliminated by distillation under reduced pressure which produces sticky residue except for aqueous extract. The concentrated crude extracts were stored at $0-4{ }^{\circ} \mathrm{C}$ until used.

\section{Experimental design}

By using OECD guidelines [8] (organization of economic cooperation and development) for study. These are made by acute toxic class method [9]. In this, stepwise procedures with three animals of the same sex were taken. Depending on mortality and moribund status of the animals on the average 2 to 4 steps may be necessary to allow judgments on the acute toxicity of the test substance. This procedure results in the use of a minimal number of animals while allowing for acceptable data for a scientific conclusion. The method uses defined doses $(100,250,500,1000$ and $2000 \mathrm{mg} / \mathrm{kg}$ bwt $)$ and the results allow a substance to be ranked and classified according to the globally harmonised system (GHS) for the classification of chemical which causes acute toxicity. The methanolic extract of Mirabilis jalapa of different doses such as $100,250,500,1000,2000 \mathrm{mg} / \mathrm{kg}$ were given orally to mice. Body weight of rats before and after termination was noted and any change in skin, fur, eyes, mucous membrane and behaviour pattern were observed and also signs of tremors, salvations, diarrhoea, lethargy, sleep and coma were noted. The methanolic and aqueous extracts of MJ of two selected doses such as 250 and $500 \mathrm{mg} / \mathrm{kg}$ body weight were given orally to the Wister rats. Aluminium hydrochloride was run by gavage for $45 \mathrm{~d}$. Gavage was performed using a syringe with a modified steel point to introduce the solution into the rat's esophagus without injuring the tissue. Rats were dividing into 11 groups such as group I [control], group II [test control, aluminium hydrochloride $100 \mathrm{mg} / \mathrm{kg}$ bwt/day], group III [standard control, received memantine $(5 \mathrm{mg} / \mathrm{kg}$ bwt)] group IV [petroleum ether extract of MJ $250 \mathrm{mg} / \mathrm{kg} \mathrm{bwt}$ ], group V [petroleum ether extract of MJ $500 \mathrm{mg} / \mathrm{kg} \mathrm{bwt}$ ], group VI [acetone extract of MJ $250 \mathrm{mg} / \mathrm{kg} \mathrm{bwt}$, group VII [acetone extract of MJ $500 \mathrm{mg} / \mathrm{kg}$ bwt], group VIII [methanolic extract of MJ $250 \mathrm{mg} / \mathrm{kg}$ bwt], group IX [methanolic extract of MJ $500 \mathrm{mg} / \mathrm{kg}$ bwt], group X [aqueous extract of MJ $250 \mathrm{mg} / \mathrm{kg}$ bwt] and group XI [aqueous extract $500 \mathrm{mg} / \mathrm{kg}$ bwt for $45 \mathrm{~d}]$. A careful record of body weight changes of all experiments groups was kept throughout the study. Rat serum was collected from different animal groups on $1^{\text {st }}, 15^{\text {th }}$, $30^{\text {th }}$ and $45^{\text {th }}$ days for estimation of marker enzymes. The animal was weighed at the beginning of the experiment, then twice a week, and finally before sacrificing them.

\section{Biochemical assessment}

Animal brain from different groups was removed by decapitation and rinsed with an ice-cold isotonic saline solution. Brains were subsequently homogenized with ice-cold $0.1 \mathrm{mmol} / \mathrm{l}$ of phosphate buffer ( $\mathrm{pH}$ 7.4). The homogenates $(10 \% \mathrm{w} / \mathrm{v})$ were then centrifuged at speed of $1000 \mathrm{rpm}$ for $15 \mathrm{~min}$ and the resultant supernatant was gathered and used for the estimation of selected biochemical parameters by analysis method.

\section{Estimation of nitrite}

Indicator for the production of nitric oxide means the accumulation of nitrite in the resultant supernatant and the production of nitric oxide was determined by spectrophotometer using Geris reagent [0.1\% $\mathrm{N}$-(1-napththyl)-ethylenediamine dihydrochloride, $1 \%$ sulfanilamide and $5 \%$ phosphoric acid]. Equal volumes of the supernatant and the Geris reagent were incubated for $10 \mathrm{~min}$ at room temperature in the dark room. The absorbance was then measured at $\lambda_{\max } 540 \mathrm{~nm}$ using a spectrophotometer. The concentration of nitrite in the supernatant was established from a sodium nitrite standard curve and expressed as a percentage of control [10].

\section{Estimation of TBARS}

The determination of lipid peroxidation was established by TBARS as per the protocol as described by Esterbauer et al. 1990. Estimation of TBARS by mixing of homogenate with trichloroacetic acid (10\%), thiobarbituric acid $(0.6 \%)$ and heated in a boiling water bath at $400 \mathrm{Cf}$ or $25 \mathrm{~min}$. TBARS was determined from the obtained absorbance data at $\lambda \max 535 \mathrm{~nm}$. Results were reported as mol of TBARS per mg of protein [11].

\section{Estimation of reduced glutathione}

Estimation of reduced glutathione was determined as described by Ellman et al. At first $1 \mathrm{ml}$ aliquot of supernatant was precipitated with $1 \mathrm{ml}$ of $4 \%$ sulfosalicylic acid and cold digested for $1 \mathrm{~h}$ at $4{ }^{\circ} \mathrm{C}$. The sample were then centrifuged at $1200 \mathrm{rpm}$ for $15 \mathrm{~min}$ at $4{ }^{\circ} \mathrm{C}$ and from the $1 \mathrm{ml}$ of the obtained supernatant were added $2.7 \mathrm{ml}$ of phosphate buffer $(0.1 \mathrm{mmol} / \mathrm{l}, \mathrm{pH}-8)$ and $0.2 \mathrm{ml}$ of 5, 5-dithio-bis-(2nitrobenzoic acid) (DTNB). The yellow color developed was measured at $\lambda \max 412 \mathrm{~nm}$ using a spectrophotometer. Results were calculated using the molar extinction coefficient of the chromophore $(1.36 \times 104 \mathrm{~mol} / \mathrm{l} / \mathrm{cm})[12]$.

\section{Estimation of SOD}

Estimation of superoxide dismutase (SOD) was established by the reported method of Kono et al., 1978. Reduction of nitrazo blue tetrazolium (NBT) was inhibited by the superoxide dismutase and is measured. The assay system consists of EDTA $0.1 \mathrm{Mm}$, sodium carbonate $50 \mathrm{mmol}$ and $96 \mathrm{mmol}$ of nitroazo blue tetrazolium (NBT). In the cuvette, $2 \mathrm{ml}$ of the above mixture, $0.05 \mathrm{ml}$ of hydroxylamine and $0.05 \mathrm{ml}$ of supernatant was added and autooxidation of hydroxylamine was measured for $2 \mathrm{~min}$ at $30 \mathrm{~s}$ interval by measuring absorbance at $\lambda \max 560 \mathrm{~nm}$ using perkin Elmer Lambda 20 spectrophotometer $[12,13]$.

\section{Estimation of catalase activity}

Catalase activity was assessed by the method of Luck et al., wherein the breakdown of $\mathrm{H}_{2} \mathrm{O}_{2}$ is measured. Briefly, $3 \mathrm{ml}$ of $\mathrm{H}_{2} \mathrm{O}_{2}$ phosphate buffer and $0.05 \mathrm{ml}$ of the supernatant of the tissue homogenate for 2 min at 30 -second intervals for $\lambda_{\max } 240 \mathrm{~nm}$. The results were expressed as micromoles of hydrogen peroxide decomposed/ $\mathrm{min} / \mathrm{mg}$ of protein [14].

\section{Estimation of acetylcholinesterase (AchE) activity}

AchE is a marker of the loss of cholinergic neurons in the forebrain. AchE activity was assessed by the Ellaman method. The assay mixture contained $0.05 \mathrm{ml}$ of supernatant, $3 \mathrm{ml}$ of sodium phosphate buffer ( $\mathrm{pH}-8), 0.1 \mathrm{ml}$ of acetylcholine iodide and $0.1 \mathrm{ml}$ of DTNB. The change in absorbance was measured for $2 \mathrm{~min}$ at 30s intervals of $\lambda \max 412 \mathrm{~nm}$. Results were reported in micromoles of acetylcholine iodide hydrolyzed/min mg of protein [15]

\section{Statistical analysis}

The biochemical assessment was analyzed by one way ANOVA post hoc comparisons between groups were made using Tukey's test, $\mathrm{p}<0.05$ was considered significant. 


\section{RESULTS AND DISCUSSION}

The effect of fractional extracts (acetone, petroleum ether, methanolic and aqueous) of Mirabilis jalapa on serum marker enzymes ALT and AST was estimated. The marker enzymes AST and ALT serve as indicators and suggestive for a disturbance of the cellular integrity induced by pathological conditions.

These enzymes used as a sensitive marker for evaluation of the protective activity. AST and ALT level was significantly higher in aluminium hydrochloride treated rats as compared to the control group. Groups treated with petroleum ether-acetone, methanolic and aqueous flower extracts of MJ at 250 and $500 \mathrm{mg} / \mathrm{kg}$ bwt showed a decreased level of AST and ALT from the 30th day of treatment as compared to the aluminium hydrochloride treated groups respectively. This finding supports the protective effect of fractional extracts (petroleum ether, acetone, methanolic and aqueous) of Mirabilis jalapa have shown very significant neuroprotective against aluminium hydrochloride-induced neurotoxicity in rats in reducing serum AST and ALT level [16].

Effect of different fractional flower extracts of Mirabilis jalapa at doses of 250 and $500 \mathrm{mg} / \mathrm{kg}$ bwt and memantine dose $(5 \mathrm{mg} / \mathrm{kg}$ ) for estimation of various biochemical parameters such as reduced glutathione, catalase and superoxide dismutase etc in rat cerebral cortex are depicted in table 1 .

Table 1: Effect of different fractional extracts of Mirabilis jalapa and memantine for estimation of various biochemical parameters in rat cerebral cortex

\begin{tabular}{|c|c|c|c|c|c|c|}
\hline Treatments & $\begin{array}{l}\text { Nitrite } \mu \mathrm{mol} / \mathrm{mg} \\
\text { of protein }\end{array}$ & $\begin{array}{l}\text { TBARS nano } \mathrm{mol} / \mathrm{mg} \\
\text { of protein }\end{array}$ & $\begin{array}{l}\text { Reduced GSH } \\
\mu \mathrm{mol} / \mathrm{mg} \text { of protein }\end{array}$ & $\begin{array}{l}\text { SODUnit/mg } \\
\text { of protein }\end{array}$ & $\begin{array}{l}\text { Catalases } \\
\text { Unit/mg of } \\
\text { protein }\end{array}$ & $\begin{array}{l}\text { AchE } \mu \mathrm{g} / \mathrm{mg} \\
\text { of protein }\end{array}$ \\
\hline Control & $125 \pm 3.2$ & $0.12 \pm 0.07$ & $70.6 \pm 1.28$ & $17.01 \pm 9.8$ & $4.28 \pm 2.4$ & $0.65 \pm 1.02$ \\
\hline Positive control & $550.6 \pm 7.64$ & $0.42 \pm 0.24$ & $51.67 \pm 2.23$ & $8.20 \pm 4.7$ & $1.2 \pm 0.69$ & $2.73 \pm 0.26$ \\
\hline $\begin{array}{l}\text { Memantine (5 } \\
\mathrm{mg} / \mathrm{kg} \text { ) }\end{array}$ & $222 \pm 2.28$ & $0.13 \pm 0.14^{\mathrm{a}}$ & $80.12 \pm 2.82$ & $18.14 \pm 1.6$ & $4.71 \pm 0.3^{\mathrm{a}}$ & $1.08 \pm 0.33$ \\
\hline $\begin{array}{l}\text { Acetone }(250 \\
\mathrm{mg} / \mathrm{kg})\end{array}$ & $270 \pm 3.02$ & $0.23 \pm 0.13$ & $68.6 \pm 0.24$ & $10.66 \pm 2.8$ & $3.5 \pm 0.9$ & $1.38 \pm 0.22$ \\
\hline $\begin{array}{l}\text { Acetone (500 } \\
\mathrm{mg} / \mathrm{kg})\end{array}$ & $262.6 \pm 5.89$ & $0.2 \pm 0.01^{b}$ & $70 \pm 0.36$ & $11.66 \pm 1.3$ & $3.63 \pm 1.2^{\mathrm{b}}$ & $1.32 \pm 0.29$ \\
\hline $\begin{array}{l}\text { Petroleum ether } \\
(250 \mathrm{mg} / \mathrm{kg})\end{array}$ & $285 \pm 5.78$ & $0.32 \pm 0.18$ & $60.0 \pm 1.12$ & $9.2 \pm 5.8$ & $3.21 \pm 1.8$ & $1.47 \pm 0.54$ \\
\hline $\begin{array}{l}\text { Petroleum ether } 500 \\
\mathrm{mg} / \mathrm{kg} \text { ) }\end{array}$ & $277 \pm 7.63$ & $0.28 \pm 0.10^{\mathrm{b}}$ & $63.3 \pm 2.16$ & $10.06 \pm 6.1$ & $3.3 \pm 1.9^{b}$ & $1.4 \pm 0.05$ \\
\hline $\begin{array}{l}\text { Methanolic (250 } \\
\mathrm{mg} / \mathrm{kg})\end{array}$ & $254 \pm 8.04$ & $0.17 \pm 0.09$ & $71.2 \pm 0.43$ & $13.7 \pm 9.01$ & $3.83 \pm 1.6$ & $1.28 \pm 1.04$ \\
\hline $\begin{array}{l}\text { Methanolic (500 } \\
\mathrm{mg} / \mathrm{kg})\end{array}$ & $245.6 \pm 6.67$ & $0.15 \pm 0.05^{b}$ & $75.01 \pm 1.26$ & $14.75 \pm 3.6$ & $4.01 \pm 2.02^{\mathrm{b}}$ & $1.2 \pm 0.87$ \\
\hline $\begin{array}{l}\text { Aqueous ( } 250 \\
\mathrm{mg} / \mathrm{kg} \text { ) }\end{array}$ & $220.5 \pm 5.73$ & $0.14 \pm 0.08$ & $77 \pm 2.75$ & $15.63 \pm 2.7$ & $4.2 \pm 2.31$ & $1.13 \pm 0.05$ \\
\hline $\begin{array}{l}\text { Aqueous (500 } \\
\mathrm{mg} / \mathrm{kg})\end{array}$ & $221 \pm 5.02$ & $0.133 \pm 0.07^{a}$ & $79.24 \pm 2.43$ & $17.24 \pm 5.2$ & $4.45 \pm 2.5^{\mathrm{a}}$ & $1.03 \pm 0.24$ \\
\hline
\end{tabular}

Values are expressed as mean $\pm \mathrm{SEM}$, ${ }^{\mathrm{a}}<0.001, \mathrm{bP}<0.01$ compared to aluminium hydrochloride treated group (one-way ANOVA followed by turkey's test)

Treatment of aluminium hydrochloride showed a significant increase in activity of nitric oxide and TBARS levels (fig. 1 and 2), while superoxide dismutase is decreased as compared to control (fig. 3). The study has investigated the protective effect of fractional flower extracts (petroleum ether, acetone, methanol and aqueous) of Mirabilis jalapa (MJ) on aluminium hydrochlorideinduced neuronal toxicity in the cerebral cortex of male wister rats treated for $45 \mathrm{~d}$.

The cerebral cortex is chosen for a number of reasons (a) aluminium hydrochloride affects the hippocampus and cortex regions more severely than any other area of the central nervous system. (b) These brain regions are known to be particularly susceptible to
Alzheimer's disease and have an important role in learning and memory functions [17]. Aluminium hydrochloride is a ubiquitous metal and has been involved in the etiology disorders and cognition dysfunction where it exacerbates brain oxidative damage causes neuronal inflammation and induces impairment in working memory. Aluminium hydrochloride was functionally altered the blood-brain barrier and produces a change in the cholinergic and noradrenergic neurotransmission [18]. It causes impaired glucose utilization, increased free-radical generation and lipid peroxidation as well as changes in phosphoinositide metabolism and protein phosphorrylation, thereby causing severe neurotoxicity. The ability of aluminium hydrochloride to interfere with the downstream effect of molecules such as cyclic GMP involved in long-term potential [19].

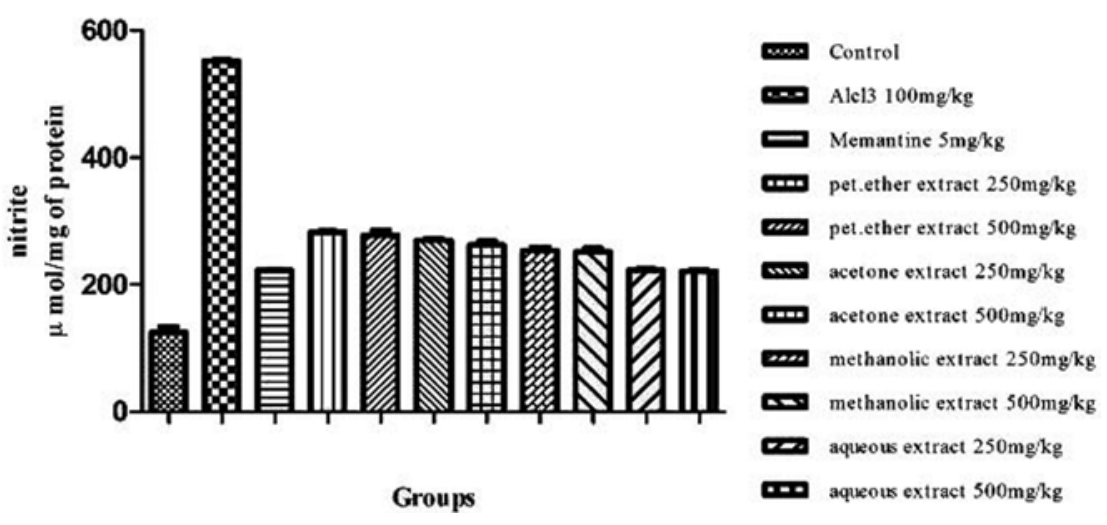

Fig. 1: Consolidated bar graph representation of MJ effects on nitric oxide 


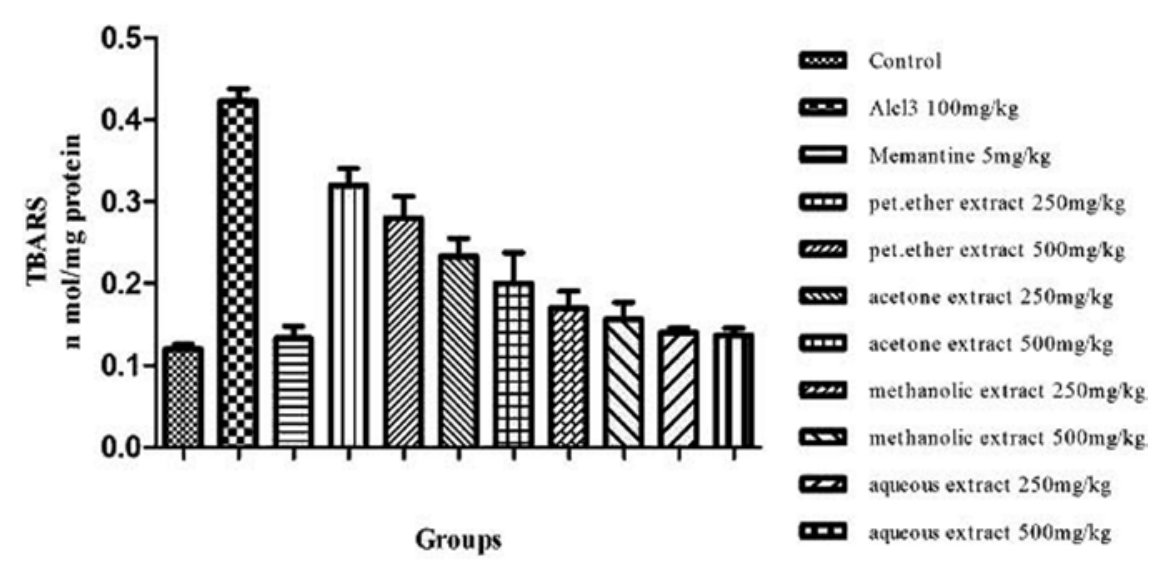

Fig. 2: Consolidated bar graph representation of MJ effects on TBARS

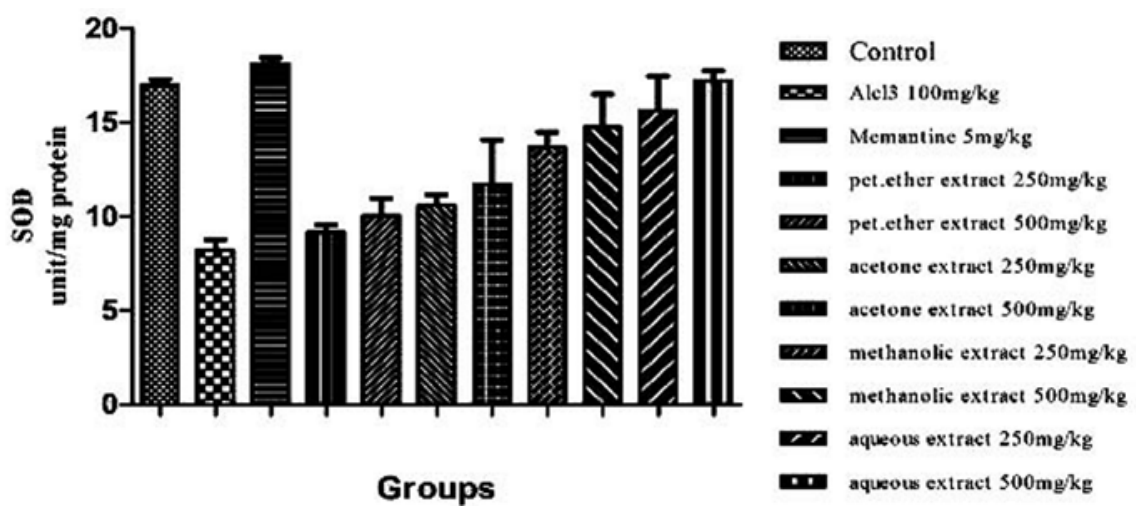

Fig. 3: Consolidated bar graph representation of MJ effects on SOD

This disruption could then explain the memory impairment and neurobehavioral deficits observed. Aluminium hydrochloride was previously considered to be a potent pro-oxidant known to enhance lipid peroxides in the cortex and hippocampus. It also targets mitochondria, causing the release of cytochrome and the activation of proapoptotic proteins like box and caspase-3, which trigger neuronal apoptotic death [20].

Memantine is a moderately, uncompetitive NMDA receptor antagonist by FDA to stabilize cognitive function and behavioural decline in several preclinical studies and in Alzheimer's disease (AD) patients with moderate to severe AD [21]. Memantine protects neurones from $A \beta$-induced toxicity and elicits the neuroprotective effects through multiple mechanisms and similarly NGF upregulation is one of the neuroprotective mechanisms for improving behavioural impairments and amyloidosis [22].

The study shows that the administration of memantine is able to prevent the changes in some oxidative stress parameters induced by aluminium hydrochloride in rats [23]. Under oxidative stress condition, SOD presents the first line of defence against superoxide as it dismutase the superoxide anion to $\mathrm{H} 2 \mathrm{O} 2$ and 02 . Catalase protects SOD by converting $\mathrm{H} 2 \mathrm{O} 2$ to water and oxygen. It is present in the peroxisomes of mammalian cells and probably serves to destroy $\mathrm{H} 2 \mathrm{O} 2$ generated by oxidase enzymes located within these subcellular organelles because oxidative stress and cognitive dysfunction are strongly correlated, agents that modulate reactive oxygen species may be potentially useful as anti-dementia agents [16]. Glutathione in its reduced form is the most abundant intracellular antioxidant and it is involved in direct scavenging of free radicals or serving as a substrate for glutathione peroxides enzyme that catalyzes the detoxification of H2O2. It is also known that SOD and catalase are the two protective enzymes and shows function for the association of detoxification of the highly reactive free radicals [24]. Sychrounous administration of fractional extraction of (petroleum ether, acetone, methanolic, and aqueous) MJ and memantine (5 mg/kg bwt) during aluminium hydrochloride treatment prevented the decrease in the activity of catalases. Increased SOD activity associated with aluminum treatment was also significantly inhibited by MJ and memantine [25].

Intracellular GSH status is a sensitive indicator of the health of a cell or tissue and its content tends to decrease soon after aluminium hydrochloride treatment. Nitrite and TBARS level estimation play a vital role in determination of neuronal transmission. Treatment of aluminium hydrochloride chloride was found to cause a significant increase in activity of nitric oxide and TBARS levels. Studies have shown that catalases and AchE activity were altered significantly with aluminium hydrochloride treatment (fig. 4). Administration of aluminium hydrochloride caused a significant increase in the AchE activity whereas the activity of $\mathrm{Na}+\mathrm{K}+\mathrm{ATPase}$ associated with aluminium hydrochloride treatment [26].

Another important factor which has been involved in influencing activities of choline acetyltransferase, acetylcholine (Ach) level and rate of its release and synthesis is nerve growth factor [27]. These effects may be mediated either by direct interactions of constituents of the extract with the cholinergic nerve terminal or transsynaptically by mechanisms such as the modulation of amyloid precursor protein secretion at one side of the synaptic cleft, which in turn can result in activation of neighbouring cells and synaptic constituent.

Hence, suggesting another possible mechanism of protective action of MJ against aluminium hydrochloride-induced neurotoxicity. It is worth mentioning that the present work was performed based on the results obtained by jyoti et al., keeping the dose of aluminium hydrochloride (per oral administration of $100 \mathrm{mg} / \mathrm{kg}$ bwt) and enhancing the time of exposure to $45 \mathrm{~d}$ [28]. 


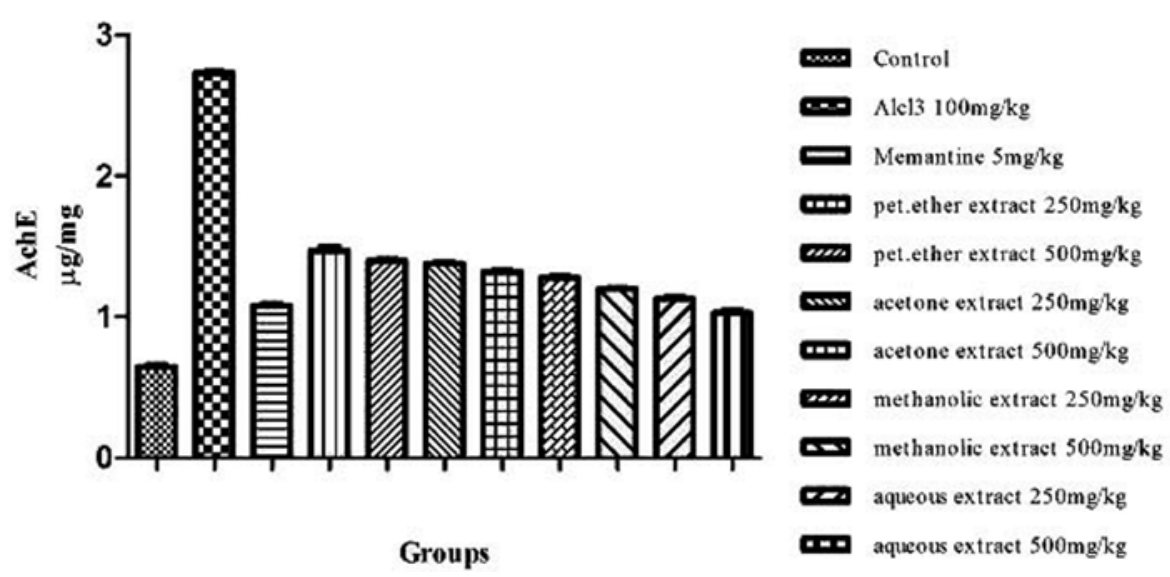

Fig. 4: Consolidated bar graph representation of MJ effects on AchE

Another reason for restricting two doses of Mirabilis jalapa and a single dose of aluminium hydrochloride is because we have to abide by the rules of the animal ethical committee and hence place a restriction on the number of animals used. The dosage of Mirabilis jalapa used in the present study has been standardised in our laboratory. The result of the present study suggests that MJ prevented aluminum-induced neurotoxicity in the cerebral cortex. Besides, inhibiting oxidative stress and histopathological alteration MJ showed promising results in normalising the altered activity/levels of protein at a cholinergic synapse induced by aluminium. From the histopathological studies, it is seen that control rat brain showing intact neuron, without any spongiosis (fig. 5A). Rat is exposed to aluminium hydrochloride $100 \mathrm{mg} / \mathrm{kg}$ showing perinuclear spaces, lipofusion and congestion in the blood vessel and prominently degenerated neuron (fig. 5B). Rat administrator to memantine $5 \mathrm{mg} / \mathrm{kg}$ showing no degenerated neuron and without spongiosis (fig. 5C). Petroleum ether extract of MJ showing the existence of degenerated neuron (fig. 5D). Acetone extract of MJ showing perinuclear spaces in the blood vessel. Methanolic extract of MJ showing no spongiosis with normal neuron and aqueous extract of MJ showing normalization of brain microstructural elements, normal neuron, intact nuclei, no spongiosis and degenerated neuron could be observed (fig. 5E). Thus, the selected extract is a possibility formulation for treating aluminium hydrochloride-induced neurotoxicity. Further studies are warranted to determine the active principle of these extracts and also determine the extract mechanism by which the phytochemicals exerts a neuroprotective effect.
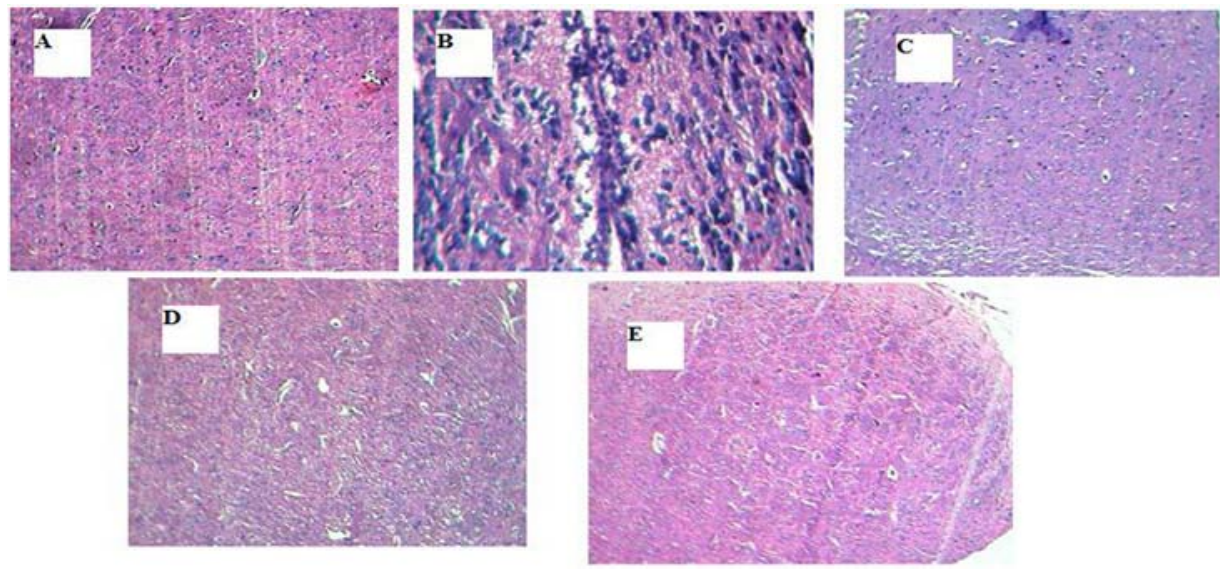

Fig. 5: Histological section of the brain was stained with haematoxylin and eosin. (A) Control rat brain showing intact neurons, without any spongiosis. (B) Rat exposed to $100 \mathrm{mg} / \mathrm{kg} / \mathrm{day} \mathrm{AlCl}_{3}$ for $6 \mathrm{w}$ with perinuclear spaces, lipofuscin deposits, congestion in the blood vessels and degenerated neurons and disrupted nuclei and oedema. (C) Rats administered memantine showed the existence of the perinuclear spaces.

(D-E) administered TSEE showed normalization of the brain microstructural elements, with normal neurons and intact nucleus and astrocytes

\section{CONCLUSION}

On the basis of our result, it may conclude that higher doses $(500$ $\mathrm{mg} / \mathrm{kg}$ bwt) of methanolic extraction of Mirabilis jalapa showed significant protection against aluminium hydrochloride-induced neurotoxicity. It may be concluded that neuroprotective effects of Mirabilis jalapa due to the presence of alkaloids, tannins and flavonoids in the flower extracts.

\section{ACKNOWLEDGMENT}

The authors would also extend their gratitude to Management of SIMS College of Pharmacy, Mangaldas Nagar, Guntur, Andhra Pradesh for providing all the facilities.

\section{AUTHORS CONTRIBUTION}

All the authors are equally contributed for this above research outcomes in the form of manuscript preparation by conducting research related to the animal work, acute toxicity, compilation, writing, copy editing of text etc.

\section{LIST OF ABBREVIATION}

AchE: Acetylcholinesterase, AD: Alzheimer's disease, ALT: Alanine transaminase, AST: Aspartate transaminase, MJ: Mirabilis jalapa, NBT: Nitroazo blue tetrazolium, SOD: Superoxide dismutase, TBARS: Thiobarbituric acid reactive substances. 


\section{CONFLICT OF INTERESTS}

The author(s) declare(s) that they have no conflicts of interest

\section{REFERENCES}

1. Subin MZ, Aleykutty NA, Vidya V, Sonu J, Visakh P. In vitro antioxidant potential of methanolic extracts of mirabilis jalapa linn. Free Radicals Antioxid 2011;1:82-6.

2. Kumar A, Prakash A, Dogra S. Neuroprotective effect of carvedilol against aluminium induced toxicity: possible behavioural and biochemical alterations in rats. Pharmacol Rep 2011;63:915-23.

3. Manno C, Lipari A, Bono V, Taiello AC, Bella VLa. Sporadic parkinson disease and amyotrophic lateral sclerosis complex (Brait-Fahn-Schwartz disease). J Neurol Sci 2013;326:104-6.

4. Maheswari SL, Murali RV, Balaji R. Aluminium induced cholinotoxicity in zebra fish brain-a sequel of oxidative stress. Int Adv Res 2014;2:322-35.

5. Singh T, Goel RK. Neuroprotective effect of Allium cepa L. in aluminium chloride induced neurotoxicity. Neurotoxicology 2015;49:1-7.

6. Baptiste AF, Marie-Elise MB, Carole H, Jean-Jacques, Yves A, Etienne $\mathrm{CH}$. Neuromelanin associated redox-active iron is increased in the substantia nigra of patients with Parkinson's disease. J Neurochem 2003;86:1142-8.

7. Sumithra M, Arunachalam G, Arunachalam G, Chitra V, Arunachalam G. Neuroprotective effect of Sargassum ilicifolium Turner c. agardh on acetylcholinesterase activity and attenuation of scopolamine-induced amnesia in rodents. Asian J Pharm Clin Res 2016;9:93-6.

8. OECD guidelines. Proc Indian Natl Sci Acad 1999;65 Suppl B:179-204.

9. Piper DW, Stiel DD. Pathogenesis of chronic peptic ulcer. DW Clin Implications Med 1986;2:7-10.

10. Dimitrios T. Analysis of nitrite and nitrate in biological fluids by assays based on the griess reaction: an appraisal of the Griess reaction in the L-arginine/nitric oxide area of research. J Chromatogr B: Anal Technol Biomed Life Sci 2007;851:51-70.

11. Hermann E, HC Kevin. Determination of aldehydic lipid peroxidation products, malonaldehyde and 4-hydroxynonenal. Methods Enzymol 1990;186:407-21.

12. Himani B, Saumya S, Promila S, Syed MW. Investigation of phytochemical composition, evaluation of antioxidant, antibacterial activities and toxicity study of Emblica officinalis and Terminalia bellirica fruits. Asian J Pharm Clin Res 2016;9:96-102.

13. Misra HP, Fridovich I. The role of superoxide anion in the auto oxidation of epinephrine and a simple assay for superoxide dismutase. J Biol Chem 1972;247:3170-5.

14. Aebi H. Catalase in vitro methods. Methods Enzymol 1984;105:121-6.

15. Zacharoula IL, Malvina GO, Alexandros GK, Fotini NL, Marigoula M. Investigation of the neuroprotective action of saffron (Crocus sativus L.) in aluminum-exposed adult mice through behavioural and neurobiochemical assessment. Food Chem Toxicol 2013;52:163-70.

16. Kumar A, Dogra S, Prakash A. Protective effect of curcumin, against aluminium hydrochloride toxicity. Possible behavioral and biochemical alterations in rats. Behavioural Brain Res 2009;205:384-90.

17. Deloncle R, Guillard 0. Mechanism of Alzeimer's disease: arguments for a neurotransmitter aluminium hydrochloride complex implication. Neurochem Res 1990;15:1239-45.

18. Yokel RA. The toxicology of aluminium in the brain: a review. Neurotoxicology 2000;21:813-28.

19. Canales JJ, Corbalan, Montoliu C, Llansola M, Monfor P, Erceg S, et al. Aluminium impairs the glutamate-nitric oxide-c-GMP pathway in cultured neurons and in rat brain in vivo: molecular mechanisms and implications for neuropathology. J Inorg Biochem 2001;87:63-9.

20. Ghribi O, DeWitt DA, Forbes MS, Arad A, Herman MM, J Savory. Cyclosporin a inhibits al-induced cytochrome c release from mitochondria in aged rabbits. J Alzheimer's Disease 2012;3:387-91.

21. Marvanova M, Lakso M, Pirhonen J, Nawa H, Wong G, Castren E. The neuroprotective agent memantine induces brain-derived neurotrophic factor and trkB receptor expression in rat brain. Mol Cell Neurosci 2001;18:247-58.

22. Drever BD, Anderson WG, Johnson H, O'Callaghan M, Seo S, Choi DY, et al. Memantine acts as a cholinergic stimulant in the mouse hippocampus. J Alzheimer's Disease 2007;12:319-33.

23. Lo D, Grossberg GT. Use of memantine for the treatment of dementia. Expert Rev Neurother 2011;11:1359-70.

24. Sondheimer JH, Mahajan SK, Rye DL, Abu-Hamdan DK, Migdal SD, Prasad AS, et al. Elevated plasma copper in chronic renal failure. Am J Clin Nutr 1988;47:896-9.

25. Benzi G, Marzatico F, Pastoris O Villa. The relationship between aging, drug treatment and the cerebral enzymatic antioxidant system. Exp Gerontol 1989;24:137-48.

26. Swegert CV, Dave KR, Katyare SS. Effect of aluminium-induced Alzheimer-like condition on oxidative energy metabolism in rat liver, brain and heart mitochondria. Mechanisms Ageing Dev 1999;112:27-42.

27. Yu SP. $\mathrm{Na}^{+} / \mathrm{K}^{+}-\mathrm{ATPase}$ : the new face of an old player in pathogenisism and apoptotic or hybrid cell death. Biochem Pharmacol 2003;66:1601-9.

28. Jyoti A, Sethi P, Sharma D. Bacopa monniera prevents from aluminium hydrochloride neurotoxicity in the cerebral cortex of rat brain. J Ethnopharmacol 2007;111:56-62.

\section{How to cite this article}

- Sitty Manohar Babu, Suryakanta Swain, Karanam Renuka. Neuroprotective activity of fractional flower extracts of Mirabilis jalapa against aluminium hydrochloride-induced neurotoxicity in male wister rats. Int J Pharm Pharm Sci 2017;9(5):216-221. 